\title{
Trykksår etter ryggmargsskade
}

\begin{abstract}
Sammendrag
Bakgrunn. Trykksår er en alvorlig komplikasjon som ofte forekommer hos pasienter med traumatisk ryggmargsskade. Formålet med denne artikkelen er å belyse risikofaktorer for trykksår og anbefale forebyggende tiltak for denne pasientgruppen.
\end{abstract}

Kunnskapsgrunnlag. Artikkelen er basert på litteratursøk i databasen PubMed og egen klinisk erfaring.

Resultater. $30-40 \%$ av ryggmargsskadepasienter i akutt- og rehabiliteringsfasen utvikler trykksår, oftest over beinfremspring, slik som sacrum, tuber ischii, hæler, malleoler og trochanter. Risikofaktorer er redusert aktivitet/ immobilitet, manglende sensibilitet, fuktighet fra inkontinent blære/tarm, muskelatrofi, tid fra skade, depresjon, røyking og dårlig ernæring. De viktigste forebyggende tiltakene er trykkavlastning, regelmessig posisjonsendring og hyppig observasjon av huden over beinfremspring.

Fortolkning. Trykksår hos pasienter med traumatisk ryggmargsskade kan i de fleste tilfeller forebygges. Dette vil spare pasientene for langvarige sykehusopphold og helsevesenet for store kostnader.

\section{Jana Midelfart Hoff \\ jmid@helse-bergen.no \\ Lise Walter Bjerke \\ Spinalenheten \\ Nevrologisk avdeling}

Paul Egil Gravem

Plastikkirurgisk avdeling

Ellen Merete Hagen

Tiina Rekand

Spinalenheten

Nevrologisk avdeling

Haukeland universitetssykehus
Trykksår, decubitus, defineres som en avgrenset skade på huden og/eller det underliggende vevet, vanligvis over beinfremspring, der skaden skyldes trykk eller trykk kombinert med skjærende krefter (1). Trykksår dannes først $i$ epidermis og sprer seg så til underliggende hud- og vevsstrukturer.

Forebygging og behandling av trykksår er nylig omtalt $i$ en oversiktsartikkel i Tidsskriftet (2). Trykksår er en særlig hyppig og alvorlig komplikasjon hos pasienter med traumatisk ryggmargsskade. Denne artikkelen omhandler forhold som er av betydning for pleie og behandling ved slik skade.

\section{Materiale og metode}

Grunnlaget for artikkelen er litteratursøk i databasen PubMed. Artiklene er vurdert ut fra forfatternes skjønn og mangeårige kliniske erfaring innenfor fagfeltet.

\section{Forekomst og epidemiologi}

Trykksår er den hyppigste av komplikasjonene ved traumatisk ryggmargsskade og fører til økt sykelighet, flere sykehusinnleggelser, lange sykehusopphold og betydelige medisinske utgifter $(3,4)$. I en studie fra USA fant man at $30-40 \%$ av pasientene med traumatisk ryggmargsskade $i$ akutt- og rehabiliteringsfasen hadde trykksår (5). I en annen studie fra USA ble det estimert at $85 \%$ av dem med ryggmargsskade vil utvikle trykksår i løpet av livet og at 7-8\% av disse vil dø av trykksårsrelaterte komplikasjoner (6).

\section{Patofysiologi og risikofaktorer}

Trykksår oppstår oftest over beinfremspring, slik som over sacrum, tuber ischii, hæler, malleoler og trochanter major. Hovedårsaken til danning av slike sår er eksternt trykk fra underlaget over en viss tid. Trykket fører til nedsatt blodtilførsel til bløtvevet, som igjen gir hypoksi i vevet, iskemi og til sist nekrose. Det er store individuelle variasjoner i hvor lenge et område må ha hatt redusert sirkulasjon for at det skal resultere i trykksår, men en tommelfingerregel sier 30-240 minutter (7). Den kliniske utfordringen er at en stor del av nekrosen kan være skjult under huden og at det kan ta flere uker før den virkelige størrelsen på og dybden av såret viser seg. Dypere vev og muskulatur er mer sensitive for trykk og iskemi enn hudvevet (8). Trykksår graderes etter graden av affeksjon av underliggende vev (1).

Den viktigste risikofaktoren for utvikling av trykksår hos pasienter med ryggmargsskade er skaderelatert nedsatt eller opphevet sensibilitet. I tillegg øker risikoen ved immobilitet, muskelatrofi, lavt fysisk aktivitetsnivå, kardiovaskulær og respiratorisk sykdom, autonom dysrefleksi, diabetes og spastisitet (5). Hos pasienter med spastisitet kan friksjon mot underlaget gi trykksår på hælene.

Hypotensjon, en velkjent komplikasjon hos pasienter med nakkeskade eller høy torakal skade og autonom dysfunksjon, kan være utløsende og må forebygges ved hjelp av medikamenter, magebelte og kompresjonsstrømper. Fuktighet fra inkontinent blære eller tarm, tid fra skadetidspunkt og depresjon er også faktorer som er påvist å øke risikoen (9).

Røyking, underernæring og feilernæring (lite proteininntak) ser ut til å gi økt risikoen for sårdanning. De som tidligere har hatt trykksår, vil ofte få residiv. Pasienter med dårlig egenomsorg, for eksempel ved misbruksproblematikk, er spesielt utsatt (10). Risikoen øker med alderen, fordi den proliferative aktiviteten i epidermis og mikrovaskulariseringen av huden reduseres samtidig som hudens elastisitet endres. Disse faktorene kan forsterke effekten av lokalt trykk og strekk på huden og gi grobunn for sårdanning (11). Innleggelse i sykehus kan i seg selv kan være en risikofaktor, spesielt når pasienten må gjennomgå operative inngrep. Vi har opplevd at pasienter med kronisk ryggmargsskade utvikler trykksår under sykehusoppholdet på grunn av utilstrekkelig hjelp og oppmerksomhet vedrørende stillingsendring og trykkavlastende utstyr.

\section{Komplikasjoner og samfunnsøkonomi}

Et trykksår vil raskt bli kolonialisert av bakterier. Det kan føre til lokal eller systemisk

\section{Hovedbudskap}

- Mange pasienter med ryggmargsskade utvikler trykksår, særlig over beinfremspring, slik som over sacrum, tuber ischii, hæler, malleoler og trochanter

- Ryggmargsskadens omfang og grad av sensibilitetsnedsettelse er viktige risikofaktorer

- Trykksår forebygges ved trykkavlastning, regelmessig posisjonsendring og hyppig observasjon av huden over beinfremspring 
infeksjon som ytterligere forverrer tilhelingsprosessen. Osteomyelitt er ikke uvanlig - i en studie fra USA med 537 ryggmargsskadede var insidensen av osteomyelitt 20,9 tilfeller per 10000 hos hospitaliserte med ryggmargsskade, mot 1,8 per 10000 hos hospitaliserte uten slik skade (12).

Det foreligger ingen sikre estimater for kostnadene ved behandling av trykksår i Norge, men tall fra Nederland fra 2002 viste at $1 \%$ av det totale helsebudsjettet ble benyttet til behandling av slike sår (13). En studie fra Storbritannia fra 2004 viste at tilsvarende kostnader utgjorde $4 \%$ av helsebudsjettet (14). Det er ingen grunn til å tro at utgiftene hos oss er mindre enn i disse landene.

\section{Hvordan forebygge trykksår}

Det er lettere å forebygge trykksår enn å få dem til å gro. De viktigste forebyggende tiltak er trykkavlastning, regelmessig posisjonsendring og hyppig observasjon av huden over beinfremspring. Alle ryggmargsskadede som er immobilisert skal ha rutiner for trykkavlastning ved regelmessig posisjonsendring i både rullestol og seng. Det er viktig at pasienten ikke blir sittende i sengen på en måte som gjør at han/hun sklir nedover mot underlaget. Dette vil føre til både skjærende krefter og friksjon (6). Sengeliggende bør hvile i 30-40 graders sideleie for å unngå høyt trykk mot trochanter (6).

Trykkavlastning er svært viktig. Pasienter med ryggmargsskade skal ha trykkavlastende underlag i seng og stol. Trykkavlastende madrass er et godt hjelpemiddel og kan benyttes hos alle uansett tilstand, men også her kan trykket på hælene bli for stort, noe som kan unngås ved å legge puter under leggene (6).

Økt aktivitetsnivå, jevnlig gjennomtøyning og ståtrening er viktige forebyggende tiltak. Hvis pasienten har residiverende trykksår, anbefales det at sittestillingen i rullestol og tilpasning av pute evalueres av et tverrfaglig team (6), enten ved henvisning til hjelpemiddelsentralenes sitteklinikker eller til en av spinalenhetene ved Sunnaas sykehus, Haukeland universitetssykehus eller St. Olavs hospital.

Pasientene må oppfordres til å sjekke huden på utsatte områder, eventuelt ved bruk av speil. Hos dem med mørk hud kan rødhet være vanskelig å se, men ved et lett trykk kan man ofte kjenne økt varme og endret konsistens i vevet. Ved å avlaste slike områder kan sår unngås. Pasienten må få hjelp til stillingsendring, snuing $i$ seng og stillingsendring $i$ stol hvis han/hun ikke klarer dette selv.

\section{Konservativ behandling}

Ved erytem og tegn på sårdanning skal området avlastes totalt. De grunnleggende behandlingsprinsippene er å holde såret rent, men ikke etterstrebe steril sårprosedyre (kroniske sår er nesten alltid kontaminert) (11). Det er viktig å opprettholde et fuktig sårmiljø. Bruk av skumbandasjer eller hydrokolloide sårplater kan være hensiktsmes- sig (6). Tørre bandasjer og kompresser i sår må unngås, da slike lager trykk og dermed motvirker tilheling. Kaviteter fylles med sårfyllere, og nekrotisk vev må fjernes (6). Man bør unngå nedkjøling av såret ved å sørge for at sårrensevæsken er temperert.

Altfor hyppige sårskift er ikke ønskelig, fordi såret trenger ro for å gro. Hvor hyppig sårskift skal utføres, må vurderes med utgangspunkt $\mathrm{i}$ sårfase og morfologisk tilstand. Et sår med mye biofilm, lukt og sekresjon skal skiftes, og debris må fjernes hyppig. Når så såret er i en fase med mye granulasjonsvev, kan godt frekvensen reduseres, ofte kan hver 3. til 5. dag være tilstrekkelig (15). Tett oppfølging og kontinuitet i oppfølgingen er viktig.

Ved moderat lokal infeksjon kan sølvbandasje og sårgel som inneholder betain (Prontosan) $i$ en periode være tilstrekkelig. Nedsatt allmenntilstand og infeksjonstegn fordrer bakteriell dyrkingprøve av sårsekret og systemisk antibiotikabehandling, først empirisk, deretter basert på det aktuelle resistensmønsteret. Ved mistanke om osteomyelitt må det foretas røntgen- eller MR-undersøkelse av området. Beinbiopsi kan være nødvendig for å påvise aktuelt bakterielt agens.

\section{Kirurgisk behandling}

Mindre sårrevisjoner med fjerning av nekrotisk vev kan utføres av lege eller sykepleier med spesialkompetanse. Større sårrevisjoner krever anestesi og må utføres av kompetent kirurg (2).

Hos yngre pasienter kan det en sjelden gang være aktuelt å eksidere et trykksår og dekke defekten med lappeplastikk (2). Pasienten må være godt informert, motivert og forberedt medisinsk og mentalt. Nødvendige hjelpemidler og oppfølging må være klargjort på forhånd.

\section{Konklusjon}

Trykksår hos pasienter med ryggmargsskade kan i de fleste tilfeller forebygges. Viktigste forebyggende tiltak er trykkavlastning ved regelmessig endring av stilling og hyppig observasjon av hud over beinfremspring. Forebygging sparer pasientene for langvarige sykehusopphold og helsevesenet for store kostnader.

\section{Jana Midelfart Hoff (f. 1972)}

er spesialist i nevrologi og dr.med. Hun er overlege ved Spinalenheten og medlem av styret for Norsk nevrologisk forening.

Ingen oppgitte interessekonflikter.

\section{Lise Walter Bjerke (f. 1951)}

er avdelingssykepleier ved Spinalenheten

og medlem i trykksårutvalget i Norsk Interessefaggruppe for Sårheling (NIFS).

Ingen oppgitte interessekonflikter.

\section{Paul Egil Gravem (f. 1948)}

er spesialist i generell kirurgi og i plastikkirurgi og overlege ved Plastikkirurgisk avdeling.

Ingen oppgitte interessekonflikter.

\section{Ellen Merete Hagen (f. 1962)}

er spesialist i nevrologi og samfunnsmedisin og assistentlege ved Seksjon for klinisk nevrofysiologi. Hun har doktorgrad i epidemiologi ved traumatiske ryggmargsskader og er postdoktor ved Universitetet i Bergen.

Ingen oppgitte interessekonflikter.

\section{Tiina Rekand (f. 1960)}

er dr.med. og spesialist i nevrologi. Hun er overlege for Spinalenheten ved Nevrologisk avdeling og medlem av styret for det norske ryggmargsskaderegisteret.

Ingen oppgitte interessekonflikter.

\section{Litteratur}

1. Anders J, Heinemann A, Leffmann C et al. Decubitus ulcers: pathophysiology and primary prevention. Dtsch Arztebl Int 2010: 107: 371-81.

2. Knudsen CW, Tønseth KA. Trykksår - forebygging og behandling. Tidsskr Nor Legeforen 2011; 131: 464-7.

3. Cardenas DD, Hoffman JM, Kirshblum S et al. Etiology and incidence of rehospitalization after traumatic spinal cord injury: a multicenter analysis. Arch Phys Med Rehabil 2004; 85: 1757-63.

4. Fuhrer MJ, Garber SL, Rintala DH et al. Pressure ulcers in community-resident persons with spinal cord injury: prevalence and risk factors. Arch Phys Med Rehabil 1993; 74: 1172-7.

5. Correa GI, Fuentes M, Gonzalez X et al. Predictive factors for pressure ulcers in the ambulatory stage of spinal cord injury patients. Spinal Cord 2006: 44: 734-9.

6. Pressure ulcer prevention and treatment following spinal cord injury: a clinical practice guideline for health professionals. Consortium for Spinal Cord Medicine. Paralyzed Veterans of America 2000. www.pva.org/publications (22.8.2011)

7. Harris AG, Leiderer R, Peer F et al. Skeletal muscle microvascular and tissue injury after varying durations of ischemia. Am J Physiol 1996; 271 . H2388-98.

8. DeLisa JA, Mikulic MA. Pressure ulcers. What to do if preventive management fails. Postgrad Med 1985: 77: 209-12, 218-20.

9. Smith BM, Guihan M, LaVela SL et al. Factors predicting pressure ulcers in veterans with spinal cord injuries. Am J Phys Med Rehabil 2008; 87: $750-7$.

10. Tate DG, Forchheimer MB, Krause JS et al. Patterns of alcohol and substance use and abuse in persons with spinal cord injury: risk factors and correlates. Arch Phys Med Rehabil 2004; 85: 1837-47.

11. Vohra RK, McCollum CN. Pressure sores. BMJ 1994; 309: 853-7.

12. Frisbie JH, Gore RL, Strymish JM et al. Vertebral osteomyelitis in paraplegia: incidence, risk factors, clinical picture. J Spinal Cord Med 2000; 23: $15-22$

13. Severens JL, Habraken JM, Duivenvoorden S et al. The cost of illness of pressure ulcers in The Netherlands. Adv Skin Wound Care 2002; 15: 72-7.

14. Bennett G. Dealey C, Posnett J. The cost of pressure ulcers in the UK. Age Ageing 2004; 33: 230-5

15. Gottrup F, Bermark S, Müller K. Lokal sårbehandling - skiftning av sårbandage. Ugeskr Læger 2007; 170: 44-6.

Mottatt 16.8. 2010, første revisjon innsendt 23.3. 2011, godkjent 6.10. 2011. Medisinsk redaktør Siri Lunde. 